\title{
Primary Non-Necrotizing Granulomatous Hypophysitis Mimicking Pituitary Adenomas
}

\author{
Hipofiz Adenomlarn Taklit Eden Primer Non-Nekrotizan \\ Granülomatöz Hipofizitler
}

Ali Erdem YILDIRIM ${ }^{1}$, Denizhan DIVANLIOGLU ${ }^{1}$, Nuri Eralp CETINALP ${ }^{1}$, Sevinc SAHIN ${ }^{2}$, Sezer KULACOGLU², Ahmed Deniz BELEN ${ }^{1}$

${ }^{1}$ Ankara Numune Research and Education Hospital, Department of Neurosurgery, Ankara, Turkey

${ }^{2}$ Ankara Numune Research and Education Hospital, Department of Pathology, Ankara, Turkey

Corresponding Author: Ali Erdem YILDIRIM / E-mail: alierdemyildirim@gmail.com

\begin{abstract}
AIM: The authors review their experience in the endoscopic endonasal transsphenoidal treatment of 5 patients, finally diagnosed as primary hypophysitis but initially assumed to be pituitary adenomas.

MATERIAL and METHODS: A retrospective study was undertaken to review 5 cases of primary non-necrotizing granulomatous hypophysitis (1.61\%) through 310 endoscopic transsphenoidally operated cases with the diagnosis of pituitary adenoma between 2009 and 2013 . All 5 cases were female without any background of autoimmunity or recent pregnancy. The initial presumptive diagnosis was pituitary adenoma for all patients. The endocrinological diagnoses of the patients were suspected Cushing's Disease, anterior pituitary deficiency with hyponatremia, hyperprolactinemia, and acromegaly. One of the patients had normal hormonal levels. All patients had macroadenomas including one invasive adenoma with skull base involvement. One of the patients (20\%) had visual field defects. All patients underwent endoscopic endonasal transsphenoidal surgery (EETS).

RESULTS: All patients had improvement of hormonal levels postoperatively except the one with anterior pituitary deficiency who required long term hormone replacement after the surgery. Mean follow-up duration was 14.8 months.

CONCLUSION: Primary granulomatous hypophysitis without any known etiological factors is very rare in the literature. It can mimic pituitary adenomas in radiological and endocrinological aspects. EETS is an effective and safe treatment especially for visual and compression symptoms.

KEYWORDS: Primary hypophysitis, Non-necrotizing, Granulomatous, Endoscopic, Secretory adenoma
\end{abstract}

öz

AMAÇ: Hipofiz adenomu ön tanısı ile endoskopik endonazal transsfenoidal (EETS) yöntemle tedavi edilen ve patoloji tanısı primer hipofizit olan 5 olguluk deneyim sunulmaktadır.

YÖNTEM ve GEREÇLER: Çalışmada 2009 ile 2013 yılları arasında endoskopik endonazal yolla opere edilen 310 hipofiz adenomu olgusu içerisinden patoloji tanısı primer nonnekrotizan granulomatöz hipofizit olan 5 olgu $(\% 1,61)$ geriye dönük olarak incelendi. Hastaların hepsi kadın cinsiyette olup, hiçbirinde gebelik ya da altta yatan otoimmün hastalık gibi bir neden yok idi. Tüm hastaların ön tanısı hipofiz adenomu idi. Hastalarda endokrinolojik olarak sırasıyla şüpheli Cushing Hastalığı, hiponatremi ile birlikte hipofizer yetmezlik, hiperprolaktinemi, normal hormonal tablo ve akromegali ile uyumlu laboratuvar değerleri saptandı. Bir tanesi kafa kaidesi tutulumu ile birlikte invaziv adenom olmak üzere tüm olgular makroadenomdu. Bir hastada görme alanı defisiti saptandı. Tüm hastalara EETS cerrahi uygulandı.

BULGULAR: Preoperatif yetmezlik bulguları olan hasta hariç tüm hastalarda postoperatif normal hormonal değerler sağlandı.Hastalar ortalama 14,8 ay takip edildi.

SONUÇ: Primer non-nekrotizan hipofizitler nedeni bilinmeyen ve nadir görülen hastalıklar olup radyolojik ve endokrinolojik olarak hipofiz adenomlarını taklit edebilirler. EETS yol ise görme ile ilgili ve bası semptomlarının kaldırılmasında güvenli ve etkili bir yöntemdir.

ANAHTAR SÖZCÜKLER: Primer hipofizit, Non-nekrotizan, Granülomatöz, Endoskopik, Sekretuar adenom

\section{INTRODUCTION}

Inflammation of the pituitary gland is a rare condition characterized by infiltration and destruction of the gland $(7,38)$. The incidence is unclear and little is known, mostly from case reports in the literature $(15,20,24,30,35)$. Inflammatory hypophysitis is classified into five sub-types: lymphocytic, granulamatous, xanthomatous, xanthogranulomatous and necrotizing (21). Lymphocytic and granulomatous hypophysitis are the most common types (5). Hypophysitis can also be classified as primary (idiopathic) hypophysitis and secondary hypophysitis. It may develop due to systemic inflammatory disorders such as tuberculosis, Wegener's granulomatosis and sarcoidosis $(12,39,42)$. The majority of inflammatory pituitary lesions occur in women, are related with the postpartum 
period and most of them are in the form of lymphocytic hypophysitis $(8,41)$. Symptoms such as headache, visual disruption and involvement of pituitary gland and stalk, which may result in endocrine dysfunction, usually occur due to the influence of a sellar mass lesion (5).

Hypophysitis cases are generally misinterpreted as pituitary adenomas because of nonspecific radiological features (37). Therefore these lesions are usually diagnosed postoperatively by histological evaluation $(13,18)$. The treatment protocol remains for primary hypophysitis controversial because of the difficulties in the treatment. Medical treatment with high doses of corticosteroid agents has led to inconsistent results $(6,9)$. Nevertheless, surgical intervention has been associated with definitive diagnosis and satisfactory outcome $(3,14,34)$.

We present 5 primary non-necrotizing granulomatous hypophysitis cases with hormonal disorder and mass effect symptoms such as headache and visual impairment in this study. All the patients underwent surgical treatment with an endoscopic endonasal transsphenoidal approach, misdiagnosed preoperatively as a pituitary adenoma.

\section{MATERIAL and METHODS}

A retrospective study was undertaken to review 5 cases of primary non-necrotizing granulomatous hypophysitis (1.61\%) through 310 endoscopic transsphenoidally operated cases with the diagnosis of pituitary adenoma between 2009 and 2013. All 5 cases were female and the mean age was 47,6 years. The patients had no history of recent pregnancy or underlying autoimmune disease. Headache, hormonal elevation, hormonal deficiency and vision loss were the most common presenting features. The initial presumptive diagnosis was pituitary adenoma in all patients. Endocrinological evaluation of the patients led to one case of suspected Cushing's Disease, one anterior pituitary deficiency with hyponatremia, one hyperprolactinemia, one normal hormonal level and one acromegaly. All patients had macroadenomas including one invasive adenoma with skull base and cavernous sinus involvement. One patient (20\%) had a visual field defect. Although they were initially diagnosed as pituitary adenomas with pre-operative radiological imaging and endocrinological evaluation, postoperative histological assessment with hematoxylin eosin ( $\mathrm{H} \& \mathrm{E})$ staining showed dense inflammatory cell and multinuclear giant cell infiltration inside a fibrotic stroma. Immunohistochemical staining revealed scattered CD68 positive histiocytes. These histopathological findings led to a diagnosis of non-necrotizing granulomatous hypophysitis (Figure 1A-D). The patients were investigated for granulomatous systemic disease after the postoperative pathological diagnosis of non-necrotizing granulomatous hypophysitis, but did not show any evidence of such disease.

\section{Patient 1}

A 40-year-old woman presented with a 3-month history of headache and weight gain. Neurological evaluation and fundoscopic examinations were normal. Pituitary Magnetic

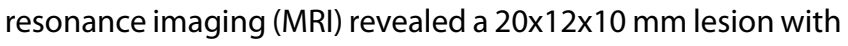

a diffuse homogenous enhancement following gadolinium administration, considered to be a macroadenoma (Figure 2A). The endocrinological evaluation revealed that serum cortisol and ACTH levels were higher than normal and the cortisol and ACTH levels were suppressed with $8 \mathrm{mg}$ dexamethazone. The patient was diagnosed as suspected Cushing's Disease. She was operated with endoscopic endonasal transsphenoidal approach and the tumor was removed totally. Surgery was uncomplicated. The postoperative period was uneventful. Postoperative serum cortisol and ACTH levels were within the normal range. There were no complaints or tumor recurrence within 14 months of follow-up.

\section{Patient 2}

A 49-year-old woman presented with a 1-month history of nausea and vomiting. Neurological evaluation and fundoscopic examinations were normal. Endocrinological and laboratory evaluations showed severe hyponatremia with a need for sodium replacement therapy due to hypopituitarism. Pituitary MR imaging revealed an 11x10x9 $\mathrm{mm}$ lesion considered to be macroadenoma, with heterogeneous enhancement following gadolinium administration (Figure 2B). The patient was operated with endoscopic endonasal transsphenoidal approach and the tumor was removed totally. Surgery was uncomplicated. The postoperative period was uneventful. There was no complaint or tumor recurrence within 16 months of follow-up under hormonal replacement therapy.

\section{Patient 3}

A 63-year-old woman presented with a 6-month history of headache and amenorrhea. Neurological evaluation and fundoscopic examination was normal. Endocrinological and laboratory assessments showed a high prolactin level that was considered to be stalk effect. Pituitary MR imaging revealed a $14 \times 16 \times 14$ mm lesion with diffuse homogenous enhancement following gadolinium administration, considered to be a macroadenoma with pituitary stalk compression (Figure $2 \mathrm{C}$ ). The patient was operated with the endoscopic endonasal transsphenoidal approach and the tumor was removed totally. Surgery was uncomplicated. The postoperative period was uneventful. Postoperative prolactin levels were within the normal range. There was no complaint or tumor recurrence within 16 months of follow up.

\section{Patient 4}

A 38-year-old Sudanese woman presented with a severe headache and visual loss for the last year. Neurological examination was remarkable for quadranopsia. The patient had been treated with radiotherapy for nasopharynx carcinoma in Sudan. Pituitary MRI revealed a 28x35x59 mm macroadenoma, with heterogeneous contrast enhancement, that invaded the right cavernous sinus, Meckel's cave, skull base and clivus with slight optical chiasm compression (Figure 2D). Endocrine and laboratory assessments were normal. The patient was operated with the endoscopic endonasal transsphenoidal approach and peroperative histological 

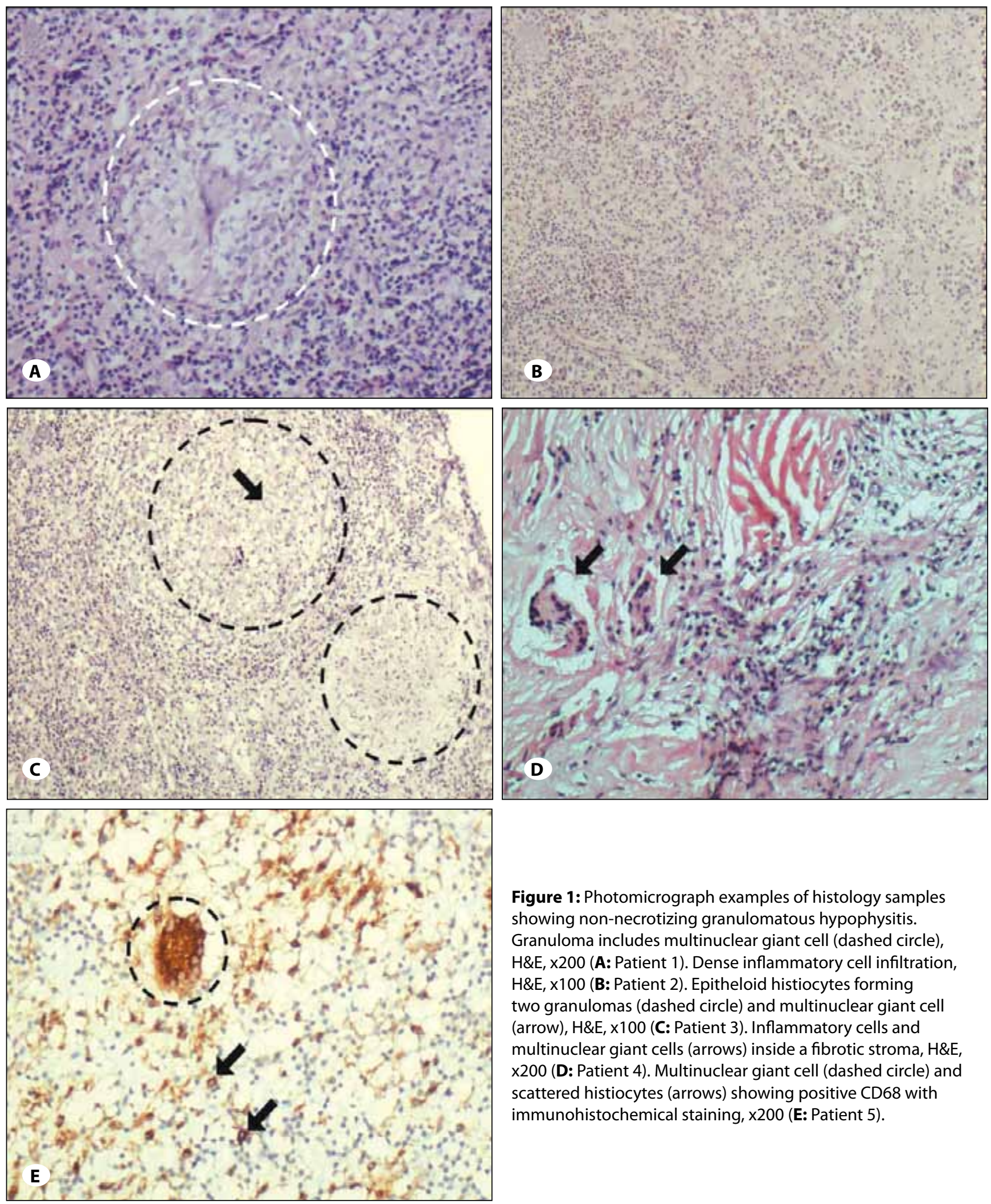

Figure 1: Photomicrograph examples of histology samples showing non-necrotizing granulomatous hypophysitis. Granuloma includes multinuclear giant cell (dashed circle), $\mathrm{H} \& \mathrm{E}, \mathrm{x200}$ (A: Patient 1). Dense inflammatory cell infiltration, $\mathrm{H} \& \mathrm{E}, \mathrm{x} 100$ (B: Patient 2). Epitheloid histiocytes forming two granulomas (dashed circle) and multinuclear giant cell (arrow), H\&E, x100 (C: Patient 3). Inflammatory cells and multinuclear giant cells (arrows) inside a fibrotic stroma, $\mathrm{H} \& \mathrm{E}$, x200 (D: Patient 4). Multinuclear giant cell (dashed circle) and scattered histiocytes (arrows) showing positive CD68 with immunohistochemical staining, x200 (E: Patient 5). 
evaluation of the patient was reported as non-necrotizing granulomatous hypophysitis. The operation was discontinued and steroid therapy was started.

\section{Patient 5}

A 48-year-old woman presented with a 6-month history of headache, enlargement of hands/feet and dyspnea. Neurological evaluation and fundoscopic examinations were normal. Pituitary MR imaging revealed a $15 \times 10 \times 10 \mathrm{~mm}$ lesion with heterogeneous enhancement following gadolinium administration and was considered as macroadenoma (Figure 2E). The endocrinological examinations revealed that serum growth hormone $(\mathrm{GH})$ and insulin like growth factor (IGF-1) levels were higher than normal range. The patient was diagnosed as acromegaly. She was operated with endoscopic endonasal transsphenoidal approach and the tumor was removed totally. Surgery was uncomplicated. The postoperative period was uneventful. Postoperative serum GH and IGF-1 levels were within normal interval for her age and gender. There were no complaints or tumor recurrence within 8 months of follow up.

\section{RESULTS}

All patients had an excellent surgical outcome. Early postoperative MRI scans were excellent in all except patient 4. Total tumor excision was performed for 4 patients (Figure 3A-D). Only one patient (Patient 4) had subtotal tumor removal. Postoperative hormonal replacement therapy was needed only in patient 2 . The other three patients had normal hormonal laboratory findings. There were no intraoperative or postoperative complications and all patients were discharged after a mean postoperative duration of 3 days. There was no detected recurrence in the 4 patients within a mean follow-up duration of 14.8 months. The patient data are summarized in the Table I.

\section{DISCUSSION}

The most common pituitary mass is adenoma while other mass lesions include metastases, cysts, hyperplasias, infections and inflammations (3). Inflammatory pituitary situations are very rare and there are few published cases. Inflammatory hypophysitis can be classified as primary or idiopatic hypophysitis and secondary hypohysitis may occur
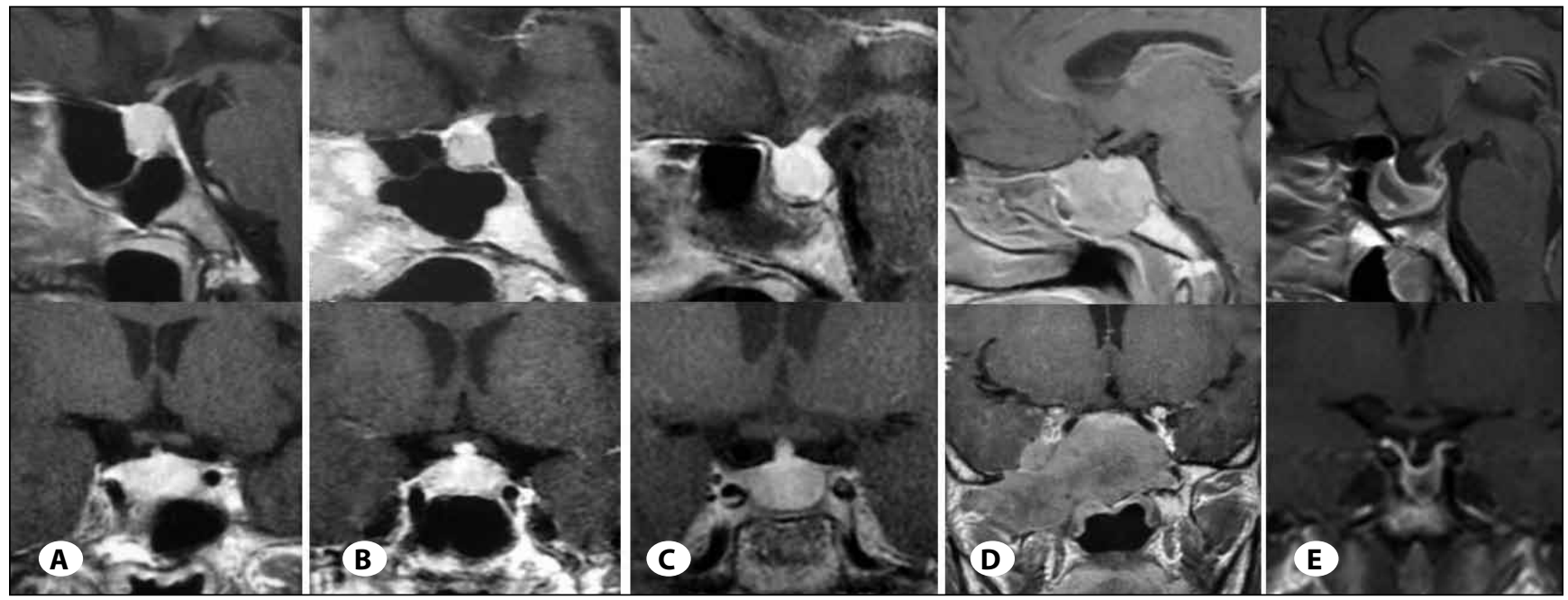

Figure 2: Preoperative sagittal and coronal contrast enhanced magnetic resonance images of patients (A: patient 1, B: patient 2, C: patient 3, D: patient 4, E: patient 5).

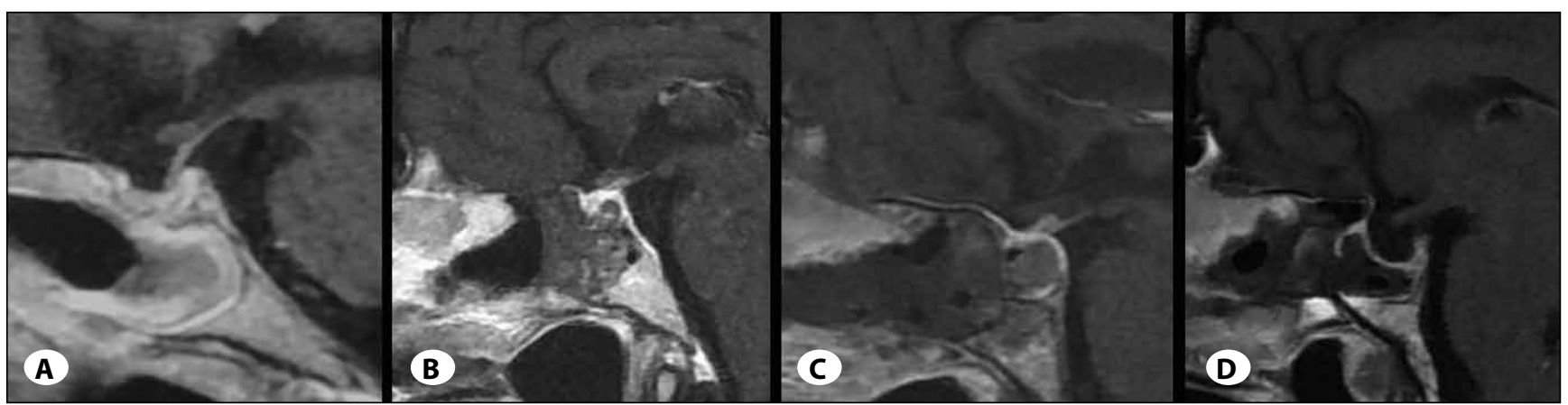

Figure 3: Postoperative sagittal contrast-enhanced magnetic resonance images of patients (A: patient 1, B: patient 2, C: patient 3, D: patient 5). 
Table I: Summary of the Patients

\begin{tabular}{|c|c|c|c|c|c|}
\hline & Patient 1 & Patient 2 & Patient 3 & Patient 4 & Patient 5 \\
\hline Age & 40 & 49 & 63 & 38 & 48 \\
\hline Gender & Female & Female & Female & Female & Female \\
\hline Signs\&Symptoms & $\begin{array}{l}\text { Headache, } \\
\text { weight gain for } \\
3 \text { months }\end{array}$ & $\begin{array}{l}\text { Nausea and } \\
\text { vomiting for } 1 \\
\text { month }\end{array}$ & $\begin{array}{l}\text { Headache and } \\
\text { amennorhea for } \\
6 \text { months }\end{array}$ & $\begin{array}{l}\text { Headache, visual } \\
\text { loss for } 1 \text { year }\end{array}$ & $\begin{array}{l}\text { Headache, } \\
\text { growth of hands/ } \\
\text { feet, dyspnea for } \\
6 \text { months }\end{array}$ \\
\hline $\begin{array}{l}\text { Neurological Exam \& } \\
\text { Fundoscopy }\end{array}$ & Normal & Normal & Normal & Quadranopsia & Normal \\
\hline Radiology & $\begin{array}{l}\text { Homogenous } \\
\text { macroadenoma }\end{array}$ & $\begin{array}{l}\text { Heterogenous } \\
\text { macroadenoma } \\
\text { with chiasm } \\
\text { compression }\end{array}$ & $\begin{array}{l}\text { Homogenous } \\
\text { macroadenoma } \\
\text { with chiasm and } \\
\text { stalk } \\
\text { compression }\end{array}$ & $\begin{array}{l}\text { Heterogenous } \\
\text { macroadenoma } \\
\text { with skull base } \\
\text { invasion and } \\
\text { chiasm } \\
\text { compression }\end{array}$ & $\begin{array}{l}\text { Heterogenous } \\
\text { macroadenoma }\end{array}$ \\
\hline $\begin{array}{l}\text { Endocrinology \& } \\
\text { Laboratory }\end{array}$ & $\begin{array}{l}\text { High cortisol } \\
\text { and ACTH }\end{array}$ & $\begin{array}{l}\text { Hypopituitarism, } \\
\text { Hyponatremia }\end{array}$ & $\begin{array}{l}\text { High prolactin } \\
\text { (stalk effect) }\end{array}$ & Normal & $\begin{array}{l}\text { High GH and } \\
\text { IGF-1 }\end{array}$ \\
\hline $\begin{array}{l}\text { Initial } \\
\text { Diagnosis }\end{array}$ & $\begin{array}{l}\text { Pituitary } \\
\text { Adenoma } \\
\text { (Cushing's } \\
\text { Disease) }\end{array}$ & $\begin{array}{l}\text { Pituitary } \\
\text { Adenoma } \\
\text { (Non-secretory) }\end{array}$ & $\begin{array}{l}\text { Pituitary } \\
\text { Adenoma } \\
\text { (Non-secretory) }\end{array}$ & $\begin{array}{l}\text { Pituitary } \\
\text { Adenoma } \\
\text { (Non-secretory) }\end{array}$ & $\begin{array}{l}\text { Pituitary } \\
\text { Adenoma (So- } \\
\text { matotropinoma) }\end{array}$ \\
\hline Tumor Removal & Total & Total & Total & Subtotal & Total \\
\hline Histological Diagnosis & $\begin{array}{l}\text { Non-necrotising } \\
\text { granulomatous } \\
\text { hypophysitis }\end{array}$ & $\begin{array}{l}\text { Non-necrotising } \\
\text { granulomatous } \\
\text { hypophysitis }\end{array}$ & $\begin{array}{l}\text { Non-necrotising } \\
\text { granulomatous } \\
\text { hypophysitis }\end{array}$ & $\begin{array}{l}\text { Non-necrotising } \\
\text { granulomatous } \\
\text { hypophysitis }\end{array}$ & $\begin{array}{l}\text { Non-necrotising } \\
\text { granulomatous } \\
\text { hypophysitis }\end{array}$ \\
\hline Follow-up & 14 months & 16 months & 16 months & 20 months & 8 months \\
\hline
\end{tabular}

due to systemic inflammatory disorders $(5,7,12)$. Primary hypophysitis is classified into five sub-types: lymphocytic, granulamatous, xanthomatous, xanthogranulomatous and necrotizing (38). Currently, it is unclear whether these entities are truly distinct or they are just different manifestations of the same disease. They have same clinical and radiological features, and there is no safe way to distinguish these entities from each other without histological examination (7). Granulomatous hypophysitis is a less commonly described entity in the literature, with a rather unclear pathogenesis. It was first described by Simmonds in 1917 (34). Granulomatous hypophysitis has an annual incidence of 1 in 10 million and accounts for less than $1 \%$ of all pituitary disorders (31). In contrast to lymphocytic hypophysitis, there is no gender predominance (7). In this study, we presented five primary granulomatous hypophysitis cases mimicking secretory, non-secretory and invasive pituitary adenomas to illustrate the clinical spectrum of this entity. All patients were female and the mean age was 47.6 years. Recent pregnancy and underlying autoimmunity were not noted.

Clinical presentation of both hypophysitis and pituitary adenomas is with headache, visual disturbances caused by optic chiasm compression, pituitary disfunctions, hyperprolactinoma, diabetes insipitus (DI), fatigue and lethargy $(6,11$,
$15,16,17,32,43)$. Headache is the first and most common symptom (16). Pituitary function is commonly affected in inflammatory hypophysitis, where ACTH and TSH deficiencies are the most frequently reported anomalies $(6,15,18,38)$. Hyperprolactinemia may develop as a result of stalk compression, presenting with amenorrhea/galactorrhea in females and decreased libido in males (1). DI may result from inflammatory destruction and/or compression of the posterior pituitary or stalk (38). All our patients had macroadenomas and headache was the most common symptom, similar to the literature. Three of the five patients had visual disruption (60\%). The endocrinological evaluation of our 3 patients revealed one anterior pituitary deficiency and hyponatremia, one hyperprolactinemia and one normal hormonal level. In contrast to previously published cases, two of our patients had an uncommon endocrinological finding: serum cortisol and ACTH levels were higher than normal and were suppressed with 8 mg dexamethasone, as is seen in Cushing's Disease (patient 1), and serum GH and IGF-1 levels were higher than normal as seen in acromegaly (patient 5). These cases are uncommon and important as they represent a hypophysitis case mimicking a secretory pituitary adenoma, in contrast to previously published hypophysitis cases, which were initially diagnosed as non-secretory adenomas. 
An inflammatory lesion is difficult to differentiate from a pituitary adenoma both clinically and radiologically. MRI plays a crucial role in the diagnosis of inflammatory hypophysitis. Characteristic MRI findings are thickening of the parasellar duramater and pituitary stalk with a contrast-enhancing sellar mass $(9,18,20)$. A triangular-shaped sellar mass, an enlarged pituitary and thickened sphenoidal mucosa are the other MRI findings that can be visualized in hypophysitis cases $(9,14)$. Pituitary stalk thickening was the most common finding and seen in $66 \%$ of granulomatous hypophysitis cases $(11,8,32)$. All these radiological features are non-specific, which is why hypophysitis cases are generally misinterpreted as pituitary adenoma and the diagnosis is usually made postoperatively by histological examination $(8,37,41)$. The initial presumptive diagnosis was pituitary adenoma in our patients and all patients underwent EETH.

The natural history of inflammatory hypophysitis is incompletely understood and its treatment is controversial $(25,26,38)$. Satisfactory responses to high-dose steroid therapy and administration of methotrexate have been reported $(2,13,39,40,44)$. Spontaneous resolution of the lesion on MRI following steroid therapy has been described, but endocrine improvement is rare (21). Insufficient treatment has been associated with granuloma formation and sudden death in hypophysitis cases $(4,10)$. Considerable side effects of long-term steroid therapy and recurrence of lesions following steroid withdrawal have been identified $(19,21$, $22,26,28,33)$. Transsphenoidal surgery is performed for both diagnosis and therapy. Surgery should be performed in cases with progressive compression or those in whom radiological and/or clinical progression occurs during conservative medical management (7). The hyperprolactinemia and mass effect such as visual disruption and stalk compression (DI) resolves after surgery in most cases $(23,27,29)$. On the other hand, definitive histological diagnosis of hypophysitis may obviate the unnecessary use of high-dose steroid therapy and facilitate the treatment of other conditions such as infection or neoplasm (21). Surgical intervention has resulted in further deterioration of visual field deficits and/or hypopituitarism in rare instances $(22,29,36)$. We operated on all our patients via the endoscopic endonasal transsphenoidal approach with the diagnosis of pituitary adenoma. The high hormonal levels (cortisol/ACTH, prolactin and GH/IGF-1) of Patient 1, 3 and 5 returned to normal and visual field defects of Patient 2, Patient 3 and Patient 4 totally recovered after the surgery. Patient 2 needed to use hormonal replacement therapy postoperatively and had no complaints within the follow-up period. Steroid therapy for hypophysitis was not begun for any of the patients before or after the surgery. There were no surgical complications during or after the operation.

\section{CONCLUSION}

Granulomatous hypophysitis is a heterogeneous group of inflammatory pituitary gland lesions. Secondary hypophysitis is more easily diagnosed as patients are likely to have other systemic manifestations of their underlying disorder. Most primary hypophysitis cases are diagnosed postoperatively and can have a variety of clinical, endocrinological and radiological presentations. Even if radiological findings do not support the diagnosis of hypophysitis, it should be kept in mind that primary hypophysitis can mimic non-secretory and invasive pituitary adenomas with mass effect or secretory adenomas with its clinical and laboratory findings.

\section{REFERENCES}

1. Ahmed SR, Aiello DP, Page R, Hopper K, Towfighi J, Santen RJ: Necrotizing infundibulohypophysitis: A unique syndrome of diabetes insipidus and hypopituitarism. J Clin Endocrinol Metab 76:1499-1504, 1993

2. Amagasa M, Yuda F, Kojima H, Noshita N, Sato S: Natural course of lymphocytic infundibuloneurohypophysitis. Clin Neuropathol 20: 229-232, 2001

3. Asa SL: Tumors of the pituitary gland, third series. Fascicle 22, Washington, DC: Armed Forces Institute of Pathology, 1998

4. Beressi N, Cohen R, Beressi JP, Dumas JL, Legrand M, Iba-Zizen MT, Modigliani E: Pseudotumoral lymphocytic hypophysitis successfully treated by corticosteroid alone: First case report. Neurosurgery 35:505-508, 1994

5. Bullmann C, Faust M, Hoffmann A, Heppner C, Jockenhövel F, Müller-Wieland D, Krone W: Five cases with central diabetes insipidus and hypogonadism as first presentation of neurosarcoidosis. Eur J Endocrinol 142:365-372, 2000

6. Buxton N, Robertson I: Lymphocytic and granulocytic hypophysitis: A single centre experience. Br J Neurosurg 15: 242-246, 2001

7. Cheung CC, Ezzat S, Smyth HS, Asa SL: The spectrum and significance of primary hypophysitis. J Clin Endocrinol Metab 86:1048-1053, 2001

8. Cosman F, Post KD, Holub DA, Wardlaw SL: Lymphocytic hypophysitis: Report of 3 new cases and review of the literature. Medicine 68: 240-256, 1989

9. Flanagan DE, Ibrahim AE, Ellison DW, Armitage M, GawneCain M, Lees PD: Inflammatory hypophysitis the spectrum of disease. Acta Neurochir 144:47-56, 2002

10. Gal R, Schwartz A, Gukovsky-Oren S, Peleg D, Goldman J, Kessler E: Lymphoid hypophysitis associated with sudden maternal death: Report of a case review of the literature. Obstet Gynecol Surv 41:619-621, 1986

11. Gazioglu N, Tuzgen S, Oz B, Kocer N, Kafadar A, Akar Z, Kuday $\mathrm{C}$ : Idiopathic granulomatous hypophysitis: Are there reliable, constant radiological and clinical diagnostic criterias? Neuroradiology 42: 890-894, 2000

12. Goyal M, Kucharczyk W, Keystone E: Granulomatous hypophysitis due to Wegener's granulomatosis. AJNR 21:1466-1469, 2000

13. Hashimoto K, Asaba K, Tamura K, Takao T, Nakamura T: A case of lymphocytic infundibuloneurohypophysitis associated with systemic lupus erythematosus. Endocr J 49:605-610, 2002

14. Holck S, Laursen H: Prolactinoma coexistent with granulomatous hypophysitis. Acta Neuropathol 61:253-257, 1983 
15. Honegger J, Fahlbusch R, Bornemann A, Hensen J, Buchfelder M, Müller M, Nomikos P: Lymphocytic and granulomatous hypophysitis: Experience with nine cases. Neurosurgery 40:713-723, 1997

16. Husain N, Husain M, Rao P: Pituitary tuberculosis mimicking idiopathic granulomatous hypophysitis. Pituitary 11:313-315, 2008

17. Iwaoka T: A case of hypopituitarism associated with Hashimoto's thyroiditis and candidiasis: Lymphocytic hypophysitis or Sheehan's syndrome? Endocr J 48:585-590, 2001

18. Krimholtz MJ, Thomas S, Bingham J, Powrie JK: Lymphocytic hypophysitis: Spontaneous resolution on MRI with progression of endocrine defect. Int J Clin Pract 55:339-340, 2001

19. Kristof RA, Van Roost D, Klingmuller D, Springer W, Schramm J: Lymphocytic hypophysitis: Non-invasive diagnosis and treatment by high dose methylprednisolone pulse therapy? J Neurol Neurosurg Psychiatry 67:398-302, 1999

20. Kristof RA, Van Roost D, Schramm J, Wichers M: Primary granulomatous hypophysitis not responsive to pulsed high dose prednisolone therapy: Case report. J Neurol Neurosurg Psychiatry 64: 693-694, 1998

21. Leung GK, Lopes MS, Thorner MO, Vance ML, Laws ER: Primary hypophysitis: A single center experience in 16 cases. J Neurosurgery101: 262-271, 2004

22. Levine SN, Benzel EC, Fowler MR, Shroyer JVI, Mirfakhraee M: Lymphocytic hypophysitis: Clinical, radiological and magnetic resonance imaging characterization. Neurosurgery 22: 937-941, 1988

23. Mazzone T, Kelly W, Ensinck J: Lymphocytic hypophysitis associated with anti parietal cell antibodies and vitamin B12 deficiency. Arch Intern Med 143:1794 -1795, 1983

24. Ng WH, Gonzales M, Kaye AH: Lymphocytic hypophysitis. J Clin Neurosci 10:409-413, 2003

25. Nishiki M, Murakami Y, Ozawa Y, Kato Y: Serum antibodies to human pituitary membrane antigens in patients with autoimmune lymphocytic hypophysitis and infundibuloneurohypophysitis. Clin Endocrinol (Oxf) 54:327-333, 2001

26. Nishioka $H$, Ito $H$, Fukushima C: Recurrent lymphocytic hypophysitis: Case report. Neurosurgery 41:684-687, 1997

27. Nussbaum CE, Okawara SH, Jacobs LS: Lymphocytic hypophysitis with involvement of the cavernous sinus and hypothalamus. Neurosurgery 28:440 - 444, 1991

28. Patel MC, Guneratne N, Haq N, West TE, Weetman AP, Clayton RN: Peripartum hypopituitarism and lymphocytic hypophysitis. QJM 88:571-580, 1995

29. Pestell RG, Best JD, Alford FP: Lymphocytic hypophysitis. The clinical spectrum of the disorder and evidence for an autoimmune pathogenesis. Clin Endocrinol (Oxf) 33:457466,1990
30. Sato N, Sze G, Endo K: Hypophysitis: Endocrinologic and dynamic MR findings. AJNR 19:439-444, 1998

31. Sautner D, Saeger W, Lu decke DK, Jansen V, Puchner MJA: Hypophysitis in surgical and autoptical specimens. Acta Neuropathol (Berl). 90:637-644, 1995

32. Scanarini $M$, d'Avelle $D$, Rotilio A, Kitromillis $N$, Mingrino S: Giant-cell granulomatous hypophysitis: A distinct clinicopathological entity. Neurosurgery 71:681-686, 1989

33. Shimon I, Berezin M, Hadani M, Tadmor R, Gross D, Karasik A: A pituitary mass and hypopituitarism: Improvement after corticosteroid therapy. Isr J Med Sci 33:58-62, 1997

34. Simmonds M: Uber das vorkommen reisenzellen in der hypophyse. Virchows Arch Pathol Anat 223:281-290, 1917

35. Skandarajah A, Ng WH, Gonzales M, Kaye AH: Lymphocytic hypophysitis mimicking pituitary macroadenoma. J Clin Neurosci 9: 586-589, 2002

36. Stelmach M, O’Day J: Rapid change in visual fields associated with suprasellar lymphocytic hypophysitis. J Clin Neurol Ophthalmol 11:19-24, 1991

37. Supler ML, Mickle JP: Lymphocytic hypophysitis: Report of a case in a man with cavernous sinus involvement. Surg Neurol 37: 472-476, 1992

38. Tanaka S, Tatsumi KI, Kimura M, Takano T, Murakami Y, Takao T, Hashimoto K, Kato Y, Amino N: Detection of autoantibodies against the pituitary-specific proteins in patients with lymphocytic hypophysitis. Eur J Endocrinol 147:767-775, 2002

39. Thodou E, Asa SL, Kontogeorgos G, Kovacs K, Horvath E, Ezzat S: Clinical case seminar: Lymphocytic hypophysitis: Clinicopathological findings. J Clin Endocrinol Metab 80: 2302- 2311, 1995

40. Tubridy N, Saunders D, Thom M, Asa SL, Powell M, Plant GT, Howard R: Infundibulohypophysitis in a man presenting with diabetes insipidus and cavernous sinus involvement. J Neurol Neurosurg Psychiatry 71:798-701, 2001

41. Unlu E, Puyan FO, Bilgi S, Hamamcioglu MK: Granulomatous hypophysitis: Presentation and MRI appearance. J Clinical Neuroscience 13: 1062-1066, 2006

42. Unluhizarci K, Bayram F, Colak R, Ozturk F, Selcuklu A, Durak $A C$, Kelestimur F: Distinct radiological and clinical appearance of lymphocytic hypophysitis. J Clin Endocrinol Metab 86: 1861-1864, 2001

43. Vasile M, Marsot-Dupuch K, Kujas M, Brunereau L, Bouchard $P_{,}$ Comoy J, Tubiana JM: Idiopathic granulomatous hypophysitis: Clinical and imaging features. Neuroradiology 39:7-11, 1997

44. Yamagami K, Yoshioka K, Sakai H, Fukumoto M, Yamakita T, Hosoi M, Ishii T, Sato T, Tanaka S, Fujii S: Treatment of lymphocytic hypophysitis by high-dose methylprednisolone pulse therapy. Inter Med 42:168-173, 2003 